\title{
Lung Cancer - a Common and Deadly Disease
}

\author{
E.W. Russi \\ Department of Internal Medicine, Pulmonary Division, University Hospital, Zürich, Switzerland
}

In Europe, lung cancer is the most frequent lethal neoplasm among men, and its incidence is rapidly rising in women. Sadly enough, early diagnosis and treatment still have a low impact on the survival of patients with this type of cancer.

Risk estimates for lung cancer vary largely from one country to another. This can be attributed to several sources of variation: factors inherent in data collection, smoking habits in the different study populations and distribution of confounders and effect modifiers.

It is well known that cigarette smoking is the major risk factor for lung cancer. In 10 case-control studies carried out in 6 European countries, which included 7,609 cases of lung cancer and 10,431 controls, odds ratios of 29.9 were found in men and 8.7 in women with attributable risks exceeding $90 \%$ for men and $60 \%$ for women [1].

With an annual age-standardized incidence rate of 61.6 per 100,000 , Turkey has the highest lung cancer incidence rate for men worldwide [2]. The incidence is much lower in females $(5.1$ per 100,000$)$, and is also considerably lower than in the USA and the UK [3]. This reflects the smoking habits of the Turkish population, where, as reported by Gaskell [4] in this issue of Respiration, the percentage of female smokers is less than half that of male smokers. A particular aspect of this study is the high proportion of patients with squamous cell carcinoma (40\%). This situation is comparable to that in other countries a few decades ago. In the meantime, the proportion of ade- nocarcinomas among lung cancers has been increasing. Improved pathologic typing has resulted in a decrease in the number of cancers classified as undifferentiated and the appropriate use of WHO definitions has resulted in many tumors formerly classified as large cell tumous being reclassified as adenocarcinoma. However, the reported increase in the proportion of adenocarcinomas cannot be explained by these factors alone. The increase in the proportion of adenocarcinomas is paralleled by a decrease in the proportion of squamous cell carcinomas and, to a lesser extent small cell cancers [5-7]. The reason for this shift is not entirely clear. It is most likely attributable to the changes in smoking habits. Smoke of unfiltered cigarettes contains large particles, which are deposited in the more central airways, whereas smoke of low-yield filter-tipped cigarettes, which is inhaled more deeply and contains smaller potentially carcinogenic particles, is associated with more peripherally located cancers, i.e. adenocarcinomas. It can be assumed, that within the following years smoking habits will change also in Turkey, which will result in a shift with an increasing proportion of adenocarcinomas and a decrease in squamous cell carcinomas.

If it is not possible to stop the smoking pandemia, it is foreseeable that the rate of lung cancer will continue to grow particularly among women. This is sad since the 5year survival has not substantially increased over the last two decades and early detection is of yet unproven impact on overall lung cancer mortality.

\begin{tabular}{ll}
\hline KARGER & ( ) 2002 S. Karger AG, Basel \\
Fax +4161306 1234 $34-7931 / 02 / 0693-0199 \$ 18.50 / 0$ \\
$\begin{array}{l}\text { E-Mail karger@karger.ch } \\
\text { www.karger.com }\end{array}$ & $\begin{array}{l}\text { Accessible online at: } \\
\text { www.karger.com/journals/res }\end{array}$
\end{tabular}

Erich W. Russi, MD

Pulmonary Division

Department of Internal Medicine, University Hospital

CH-8091 Zürich (Switzerland)

Tel. +41 125538 28, Fax +41 125544 51, E-Mail erich.russi@dim.usz.ch 


\section{References}

1 Simonato L, Agudo A, Ahrens W, Benhamou E, Benhamou S, Boffetta P, Brennan P, Darby SC, Forastiere F, Fortes C, Gaborieau V, Gerken M, Gonzales CA, Jockel KH, Kreuzer M, Merletti F, Nyberg F, Pershagen G, Pohlabeln H, Rosch F, Whitley E, Wichmann HE, Zambon P: Lung cancer and cigarette smoking in Europe: An update of risk estimates and an assessment of inter-country heterogeneity. Int $\mathbf{J}$ Cancer 2001;91:876-887.

2 Fidaner C, Eser SY, Parkin DM: Incidence in Izmir in 1993-1994: First results from Izmir Cancer Registry. Eur J Cancer 2001;37:83-92.

3 Schottenfeld D: Etiology and epidemiology of lung cancer; in Pass HI, Mitchell JB, Johnson DH, Turrisi AT, Minna JD (eds): Lung Cancer. Baltimore, Lippincott/Williams \& Wilkins, 2000, p 369.
4 Goksel T and the Turkish Thoracic Society, Lung and Pleural Malignancies Study Group: Pattern of lung cancer in Turkey, 1994-1998. Respiration 2002;69:207-210.

5 Levi F, Franceschi S, Vecchia C, Randimbison L, Te VC: Lung carcinoma trends by histologic type in Vaud and Neuchâtel, Switzerland, 1974-1994. Cancer 1997;79:906-914.

6 Aucherbach O, Garfinkel L: The changing pattern of lung carcinoma. Cancer 1991;68:19731977.

7 Charloux A, Quoix E, Wolkove N, Small D, Pauli G, Kreisman H: The increasing incidence of lung adenocarcinoma: Reality or artifact? A review of the epidemiology of lung adenocarcinoma. Int J Epidemiol 1997;26:14-23. 